\title{
Low-level laser therapy in periarticular morphological aspects of the knee of Wistar rats in rheumatoid arthritis model
}

\author{
Laser de baixa intensidade nos aspectos morfológicos periarticulares do joelho de ratos Wistar \\ em modelo de artrite reumatoide
}

Morgana Neves ${ }^{1}$, Alana Ludemila de Freitas Tavares ${ }^{1}$, Ana Caroline Barbosa Retameiro', Taciane Stein da Silva Leal ${ }^{1}$, Lucinéia de Fátima Chasko Ribeiro ${ }^{1}$, Gladson Ricardo Flor Bertolini ${ }^{1}$

DOI 10.5935/2595-0118.20200003

\section{ABSTRACT}

BACKGROUND AND OBJECTIVES: The deleterious effects of rheumatoid arthritis on periarticular tissues have not yet been fully elucidated. Therefore, the search for treatments that can modulate the inflammatory profile and tissue remodeling is pertinent. The present study evaluated the effects of low-level laser therapy (LLLT) on the morphology of periarticular tissues and synovial membrane of rats in a rheumatoid arthritis model.

METHODS: Sixty-four male rats were divided into acute (7 days) and chronic (28 days) inflammatory periods, with four groups ( $\mathrm{n}=8$ ) each, being: CG (control group), LG (lesion group), CLaG (laser control group) and LLaG (laser lesion group). The animals of the lesion groups received two inoculations of Freund's Complete Adjuvant at a concentration of $50 \mu \mathrm{L}$, the first at the base of the tail, and the second at the right knee. The animals in the control groups were injected with isotonic sodium chloride solution. The ClaG and LLaG were treated with $660 \mathrm{~nm} \mathrm{LBI}, 5 \mathrm{~J} / \mathrm{cm}^{2}$ in the right knee. After the experimental period, the animals were euthanized, and the knees were processed for light microscopy.

RESULTS: The CG and CLaG morphological analysis had normal aspects. The LG showed synovitis, femur, and tibia with changes in the periosteum, with inflammatory cells and bone modifications. In the LLaG, the synovial membrane showed signs of improvement. Bone tissue in the chronic period showed morphological aspects, denoting tissue remodeling.

Morgana Neves - Dhttps://orcid.org/0000-0002-7639-4048;

Alana Ludemila de Freitas Tavares - Dhttps://orcid.org/0000-0002-8687-1231;

Ana Caroline Barbosa Retameiro - Dhttps://orcid.org/0000-0002-7783-1924;

Taciane Stein da Silva Leal - Dhttps://orcid.org/0000-0002-4936-7036;

Lucinéia de Fátima Chasko Ribeiro - Dhttps://orcid.org/0000-0001-5174-7399;

Gladson Ricardo Flor Bertolini - Dhttps://orcid.org/0000-0003-0565-2019.

1. Universidade Estadual do Oeste do Paraná, Programa de Biociências e Saúde, Cascavel, PR, Brasil.

Submitted on September 24, 2019.

Accepted for publication on December 11, 2019

Conflict of interests: none - Sponsoring sources: CNPq - Conselho Nacional de Desenvolvimento Científico e Tecnológico.

Correspondence to:

Morgana Neves

Rua: Ataulfo Alves, 84

85815-200 Cascavel, PR, Brasil.

E-mail: morgananeves26@gmail.com

(C) Sociedade Brasileira para o Estudo da Dor
CONCLUSION: The experimental model was efficient in simulating inflammatory tissue events, and the low-level laser therapy showed beneficial effects on the morphology of the periarticular tissues.

Keywords: Knee joint, Laser therapy, Rheumatoid arthritis.

\section{RESUMO}

JUSTIFICATIVA E OBJETIVOS: Os efeitos deletérios da artrite reumatoide nos tecidos periarticulares ainda náo estáo totalmente elucidados, sendo pertinente a busca por tratamentos que possam modular o perfil inflamatório e a remodelação tecidual. O presente estudo avaliou os efeitos do laser de baixa intensidade (LBI) na morfologia dos tecidos periarticulares e membrana sinovial de ratos submetidos à um modelo de artrite reumatoide. MÉTODOS: Para tanto, 64 ratos machos foram divididos em períodos inflamatórios agudo (7 dias) e crônico (28 dias), com 4 grupos $(\mathrm{n}=8)$ cada, sendo: GC (grupo controle), GL (grupo lesão), GCLa (grupo controle laser) e GLLa (grupo lesão laser). Os animais dos grupos lesão foram submetidos a duas inoculações de Adjuvante Completo de Freund na concentraçáo de $50 \mu \mathrm{L}$, sendo a primeira na base da cauda e a segunda no joelho direito. Os animais do grupo controle foram submetidos a injeçôes com solução isotônica de cloreto de sódio. Os grupos GCla e GLLa foram tratados com LBI $660 \mathrm{~nm}$, pontual no joelho direito, $5 \mathrm{~J} /$ $\mathrm{cm}^{2}$. Após o período experimental, os animais foram eutanasiados e os joelhos processados para análises em microscopia de luz. RESULTADOS: Na análise morfológica, GC e GCLa apresentaram aspectos normais. O GL apresentou sinovite, fêmur e tíbia com alteraçôes no periósteo, com células inflamatórias e modificações ósseas. A membrana sinovial mostrou sinais de melhora no GLLa. No período crônico, o tecido ósseo apresentou aspectos morfológicos, denotando remodelação tecidual.

CONCLUSÁO: O modelo experimental foi eficiente em simular os eventos inflamatórios teciduais, e o laser de baixa intensidade apresentou efeitos benéficos sobre a morfologia dos tecidos periarticulares.

Descritores: Articulação do joelho, Artrite reumatoide, Terapia a laser.

\section{INTRODUCTION}

Rheumatoid arthritis (RA) is characterized as an inflammatory, systemic, autoimmune disease that affects joint tissue and periarticular structures ${ }^{1}$. Symmetry is a fundamental feature 
of the disease that evolves from asymmetric to symmetrical, with the progression of pathological manifestations. Initial inflammatory events affect the synovial membrane, presenting cellular hyperplasia and intense inflammatory process, denoting synovitis ${ }^{2}$.

The synovial membrane has innervation marked by the presence of positive nerve fibers for proinflammatory neuropeptides, such as substance $\mathrm{P}(\mathrm{s} \mathrm{P})$ and calcitonin gene-related peptide (CGRP), both in the intimal and subintimal layers and around the blood vessels ${ }^{3}$. Such neuropeptides are the result of antidromic nerve conduction, reaching the affected joint causing progeny effects of chronic inflammatory joint processes, characterized by neurogenic inflammation ${ }^{4}$. The injurious stimulus, together with the onset of inflammation triggered by events of the immune system, such as that occurring in RA, sensitize the primary nociceptive neurons, and in response, the exacerbation of pain and inflammation occurs.

Among the features of conservative treatments used to control pain and modulation of inflammatory events is the Low-Intensity Laser (LIL). This therapy is effective in stimulating wound healing, reducing the inflammatory process and analgesia, and the primary target of irradiated light is cytochrome C oxidase, located in mitochondria. The interaction results in increased metabolism, leading to signal transduction to other cell regions ${ }^{5}$ favoring tissue repair.

The use of physical resources may be associated with other therapies already established for inflammatory control of the disease, characterized by joint cartilage degradation and inflammation of periarticular tissues, leading to reduced functional capacity, and pathological signs found in patients with $\mathrm{RA}^{6}$. However, LIL has different effects on tissues according to the parameters of use, such as dose, wavelength, and application site.

Studies on the deleterious effects of RA on the synovial membrane are scarce, and little is known about these actions on periarticular bone tissue. Moreover, as these important structures are involved in joint function, the specificity of conservative treatments that can modulate the inflammatory profile and periarticular tissue remodeling is relevant to enable the maintenance of the function and the quality of life of individuals affected by the disease that has a chronic character.

The hypothesis of the study is that the disease may induce tissue effects beyond the synovial fluid, but also in adjacent tissues such as the synovial membrane and peripheral bone region. Also, check whether LIL, due to its properties, demonstrates beneficial effects on these tissues. Given the above, this study aimed to evaluate if the LIL has effects on the morphology of the periarticular tissues of rats submitted to experimental rheumatoid arthritis.

\section{METHODS}

The study was an experimental and randomized study, composed of 64 male Wistar rats, 15 weeks old, weighing $300 \pm 19$ g, kept in polypropylene plastic boxes, with ad libitum access to food and water, temperature-controlled at $21^{\circ} \mathrm{C} \pm 1^{\circ} \mathrm{C}$, and 12 -hour light/ dark photoperiod.
The animals were randomized using the Microsoft Excel 2016 software and separated into two inflammatory periods of the disease, acute ( 7 days of inflammation) and chronic (28 days of inflammation). They were further subdivided into four groups each, CG (control group), IG (injury group), LaCG (laser control group), and LaIG (laser injury group) (Figure 1).

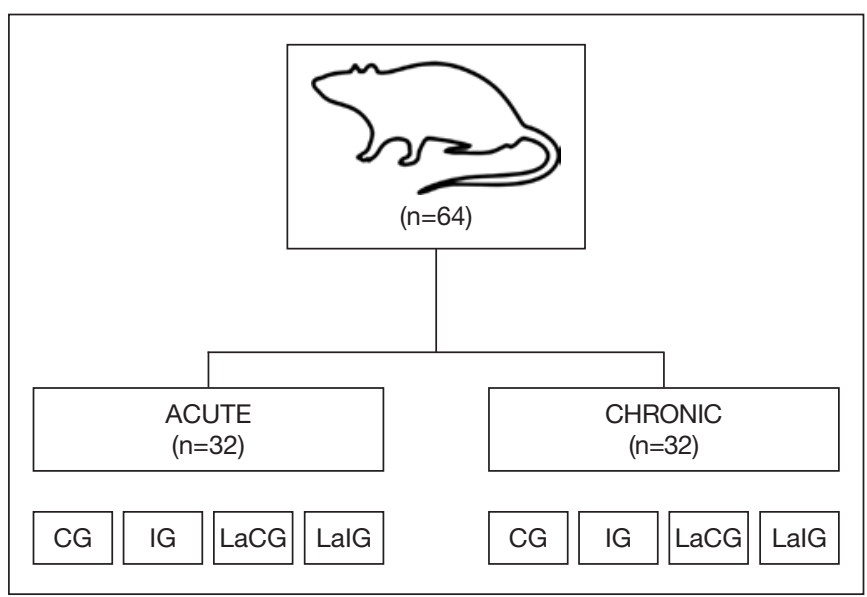

Figure 1. Diagram of sample groups

Source: Author.

$\mathrm{CG}$ = control group; IG = injury group; $\mathrm{LaCG}=$ laser control group; LalG = laser injury group.

Experimental model of rheumatoid arthritis induced by Freund's Complete Adjuvant

Initially, the animals underwent a pre-sensitization protocol ${ }^{7}$ by intradermal inoculation at the base of the tail of $50 \mu \mathrm{L}$ of FCA (Freund's Complete Adjuvant, Difco', 0.5mg/mL, Mycobacterium butirycum) for the animals of IG and LaIG, or $0.9 \%$ physiological solution (PS), Aster ${ }^{\circ}$ for CG, and LaCG animals. To this end, the substance administration area was shaved and submitted to asepsis of the injection site with $1 \%$ iodized alcohol $($ Rialcool $)$. Then the animals were injected with a $1 \mathrm{~mL}$ syringe and $13 \times 4.5 \mathrm{~mm}$ needle. The needle was inserted approximately $1 \mathrm{~cm}$ into the base of the tail subcutaneously. This intradermal injection procedure was the first inflammatory stimulus seven days before the intraarticular injection.

Intraarticular injection of $50 \mu \mathrm{L}(0.5 \mathrm{mg} / \mathrm{mL})$ of FCA or PS was administered to the right tibiofemoral joint of the animals. The animals were contained manually. The anterior knee area of the right pelvic limb was shaved, and asepsis was performed with $1 \%$ iodized alcohol. Then the injection was given with a $1 \mathrm{~mL}$ syringe and $13 \times 4.5 \mathrm{~mm}$ needle.

\section{Treatment Protocol}

The animals of groups LaCG and LaIG received the treatment with LIL ${ }^{5,8}$ (Laserpulse - Ibramed ${ }^{\circ}$ ), in the knee region of the sensitized pelvic limb. The application points were anterior to the patella, medial face in the tibiofemoral joint, lateral face in the tibiofibular joint, and posterior in the popliteal region. The treatment parameters were: four-point point technique, 660-nanometer wavelength, $30 \mathrm{~mW}$ power, spot area: $0.06 \mathrm{~cm}^{2}$, energy density: $5 \mathrm{~J} / \mathrm{cm}^{2}$ per point, time per point: 10 seconds, energy total per point: $0.003 \mathrm{~J}$, totaling four applications in animals of 
the acute group, and 14 applications in animals of the chronic inflammatory period in intercalated days. The equipment was checked for potency before treatment began.

\section{Morphological analysis}

After the experimental period, animals from acute (7 days of inflammation) and chronic (28 days) inflammatory period were euthanized by guillotine decapitation, previously anesthetized with an intraperitoneal injection of ketamine hydrochloride (Ketalar - Brazil, 95mg/kg) and xylazine (Xilazin - Brazil, 12mg/ $\mathrm{kg}$ ). After checking the animal's state of consciousness (observed due to the lack of motor response to the tail pinch and interdigital folds), the right and left knee joints were dissected, reduced in tibial and femoral transverse sections and fixed in methacarn (70\% methanol, 20\% chloroform, 10\% glacial acetic acid) for 48 hours. Then the pieces were set in $70 \%$ alcohol (Neon) for 15 days.

The material was washed for 24 hours in running water. The joints were decalcified in 5\% trichloroacetic acid (Neon ${ }^{\circ}$ ) for seven days, following a routine histological procedure for inclusion in paraffin (Alphatec). Sagittal plane sections were performed on Olympus CUT 4055 microtome, $7 \mu \mathrm{m}$ thick, and mounted on glass slides. For staining, hematoxylin and eosin protocol (Synth') was used. The slides were analyzed under a light microscope and photomicrographed under an Olympus DP71 (USA) microscope. In the morphological analysis, normal aspects and changes in the synovial membrane and bone periarticular region of the femur and tibia were observed (Figure 2).

The Committee of Ethics in the Use of Animals (CEUA) of the State University of the West of Paraná (UNIOESTE) approved this study on $10 / 27 / 2017$.

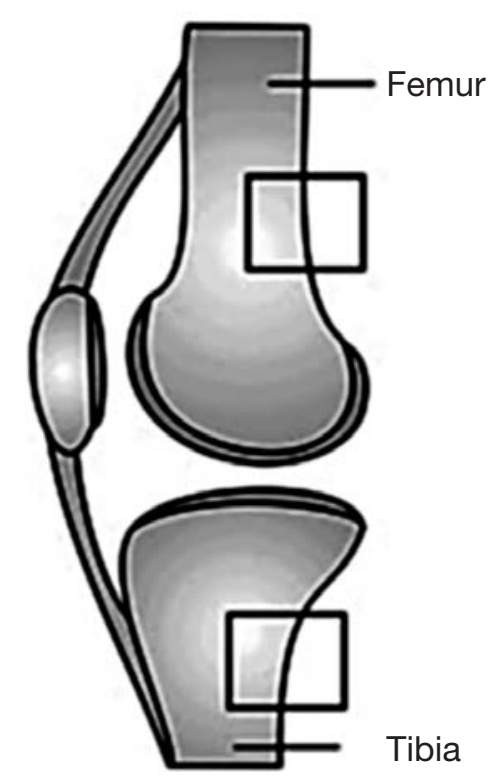

Figure 2. Diagram of the knee joint, showing the periarticular analysis sites of the femur and tibia (demarcated field)

\section{RESULTS}

The morphological analysis of the CG synovial membrane (Figure $3 \mathrm{~A}, \mathrm{~B}, \mathrm{C}, \mathrm{D})$ presents normal aspects of the synovial membrane organized in two layers of cells (synoviocytes) in the synovial intima, and subintima, with a predominance of adipose cells, blood vessels and connective without changes. LaCG animals (Figure 3I, J, K, L) presented similar morphological aspects to CG.

However, the synovial membrane of IG animals (Figure 3C, D, $\mathrm{E}, \mathrm{F})$ revealed an intense inflammatory process, with disorganized synovial intima thickening as to the epithelioid distribution of synoviocytes. Subintima with the absence of adipocytes, increased number of blood vessels, characterizing synovial joints. In LaIG (Figure 3I, J, K, L), the synovial membrane showed discrete cell organization and adipocyte reorganization, showing tissue recovery.

In acute IG animals (Figure 3F), the left pelvic limb (non-sensitized) showed morphological changes in the synovial membrane, which was not observed in animals in the chronic group, which maintained normal morphological aspects in the non-sensitized limb.

In the analysis of the periarticular region of the femur (Figure 4) and tibia (Figure 5) of the animals of the control group (A, $\mathrm{B}, \mathrm{C}, \mathrm{D})$, normal aspects of the bone tissue were verified, with periosteum in its osteogenic and fibrous layers, bone matrix with the appearance of compact bone and presence of blood vessels. In the animals of IG (E, F, G, H), in the femur (Figure 4) and tibia (Figure 5), there were morphological differences compared to the $\mathrm{CG}$, the tissue presents with intense inflammatory process in the periosteum, in the osteogenic layer, presence of differentiated inflammatory cells, gaps and modification of the compact bone in the bone matrix region to a feature of spongy bone.

Periarticular morphological modifications were found with greater evidence in both the femur and tibia of animals in the acute group, still presenting alterations in the non-sensitized contralateral limb (Figure 4).

Femur and tibia of LaIG animals (F, G, H, I), in the acute period, presented morphological aspects similar to IG. In the chronic period, there was tissue remodeling with morphological similarities to the CG.

\section{DISCUSSION}

In this study, two inoculations of FCA containing Mycobacterium butyricum induced the appearance of significant morphological changes, including synovial membrane hyperplasia with feature synovitis and periarticular bone modifications in the femur and tibia. A study postulated that adequate RA induction consists of two injections of FCA containing an attenuated mycobacterium, considering the classification of the disease, autoimmune, the model is used through pre-sensitization of animals ${ }^{7}$.

The pathogenesis of RA can be influenced by the inflammatory potentials of spinal $\operatorname{cord}^{8}$. Stimuli such as mechanical trauma, $\mathrm{pH}$ changes, presence of inflammatory mediators, can trigger a process called neurogenic inflammation', which reflects the release of neurotransmitters from the primary afferent, such as 


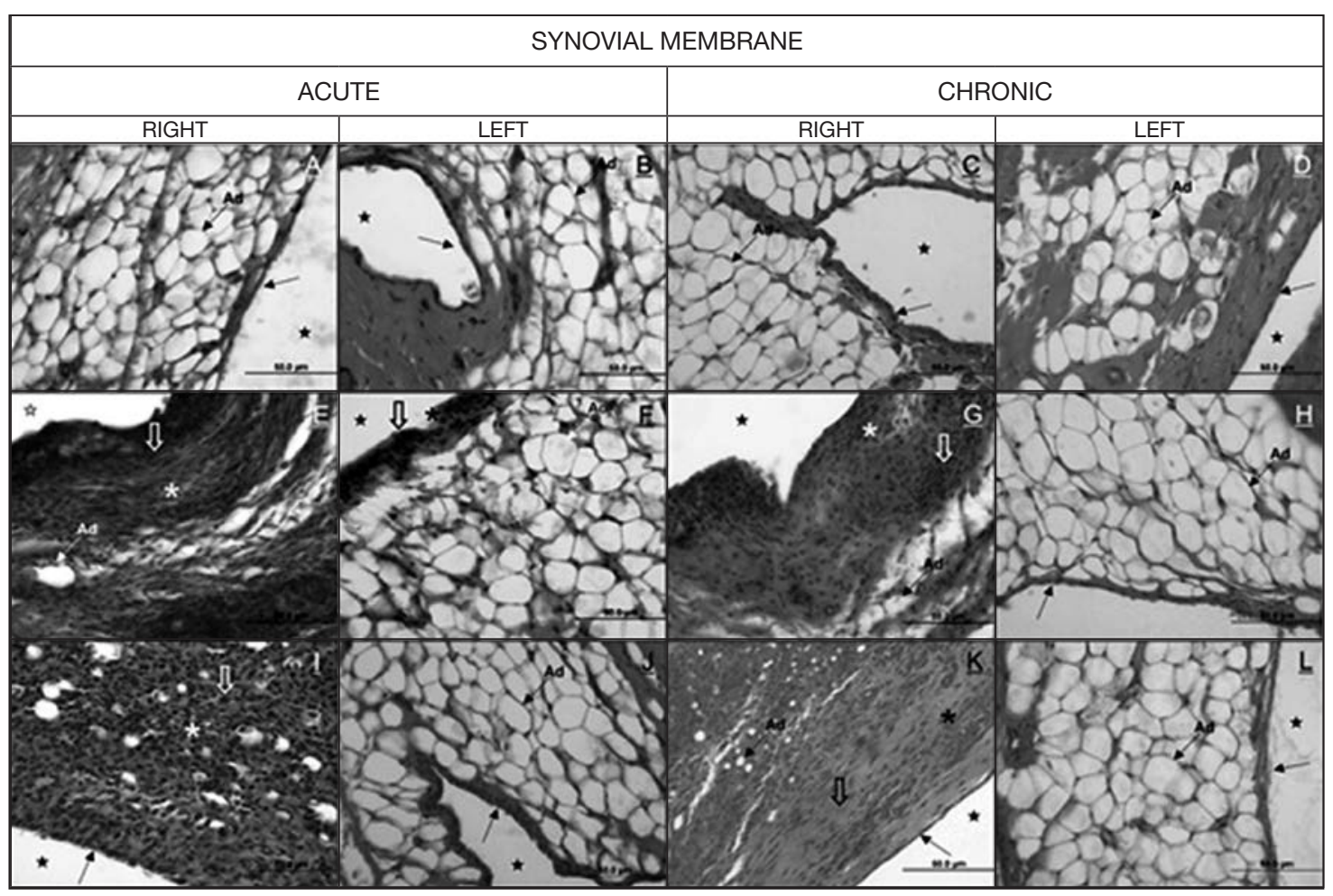

Figure 3. Photomicrographs of the synovial membrane, periods of acute and chronic inflammation, right and left limbs, respectively.

Sagittal section, hematoxylin, and eosin staining. CG (A, B, C, D) shows normal aspects of the two-layered synovial membrane, the synovial intima, with synoviocytes distributed in layers (arrow), subintima organized with a predominance of adipocytes (Ad), joint cavity (star) without inflammatory infiltrate. In IG (E, F, G, H), the synovial membrane with an intense inflammatory process (hollow arrow), thickening of the synovial intima (asterisk), and decrease of the adipose cells (Ad) in the subintima. In LaIG (I, J, K, L) acute inflammatory period denotes tissue recovery with slight adipocyte reorganization.

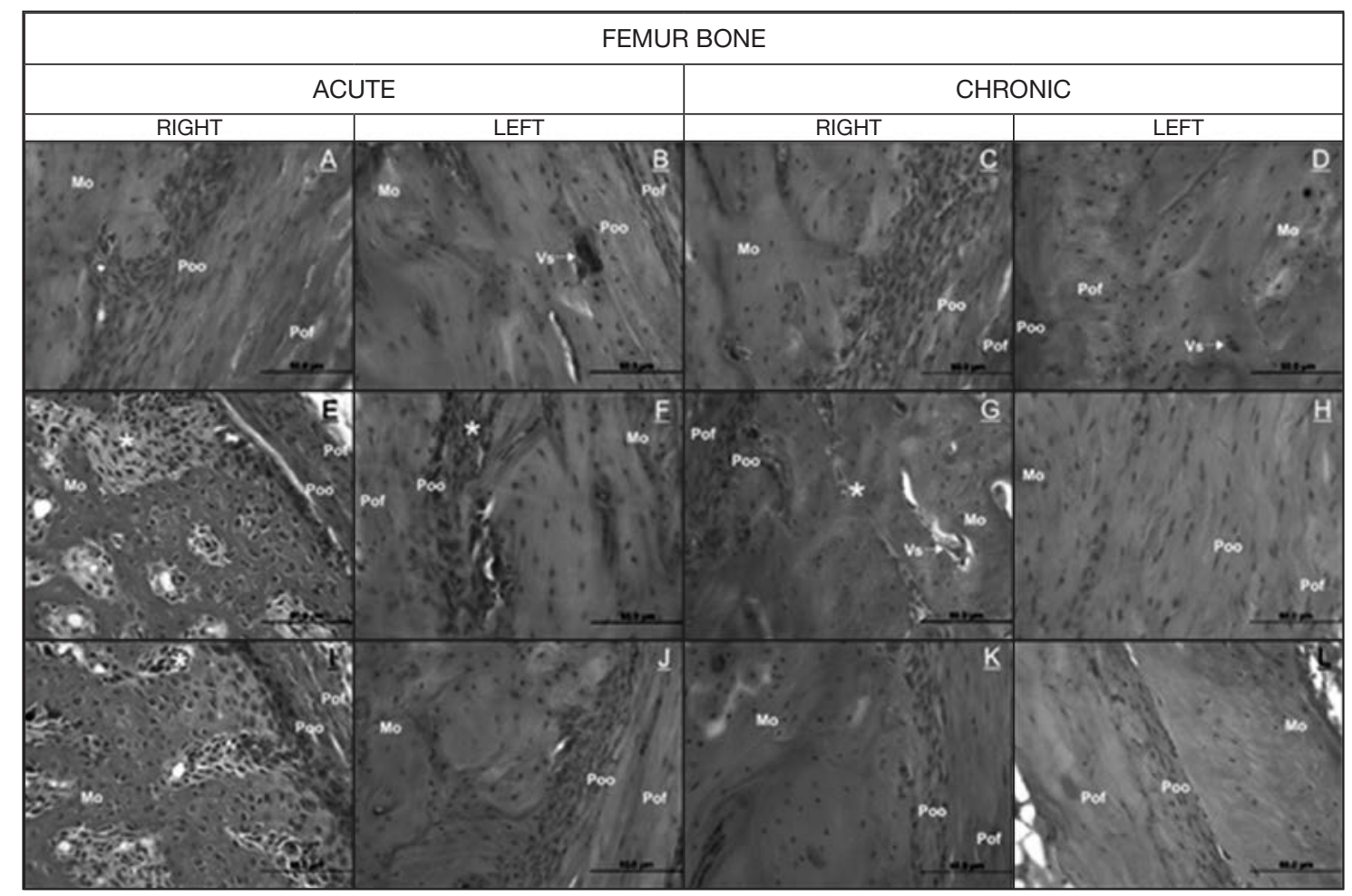

Figure 4. Photomicrographs of the femur, periarticular peripheral region, acute and chronic inflammatory period, right and left respectively. Longitudinal section, hematoxylin, and eosin staining. CG (A, B, C, D) normal aspects of bone tissue, periosteum in its fibrous (Pof), osteogenic (Poo), and bone matrix (Mo) layers with the presence of blood vessels (Vs). IG (E, F, G, H) tissue denotes the presence of inflammatory cells and modification of compact bone to feature of spongy bone (asterisk). LalG (I, J) in the acute inflammatory period, have morphological aspects similar to IG, with the onset of tissue remodeling. In LalG chronic inflammatory period $(K, L)$ reveals similarities to $\mathbf{C G}$ with tissue remodeling. 


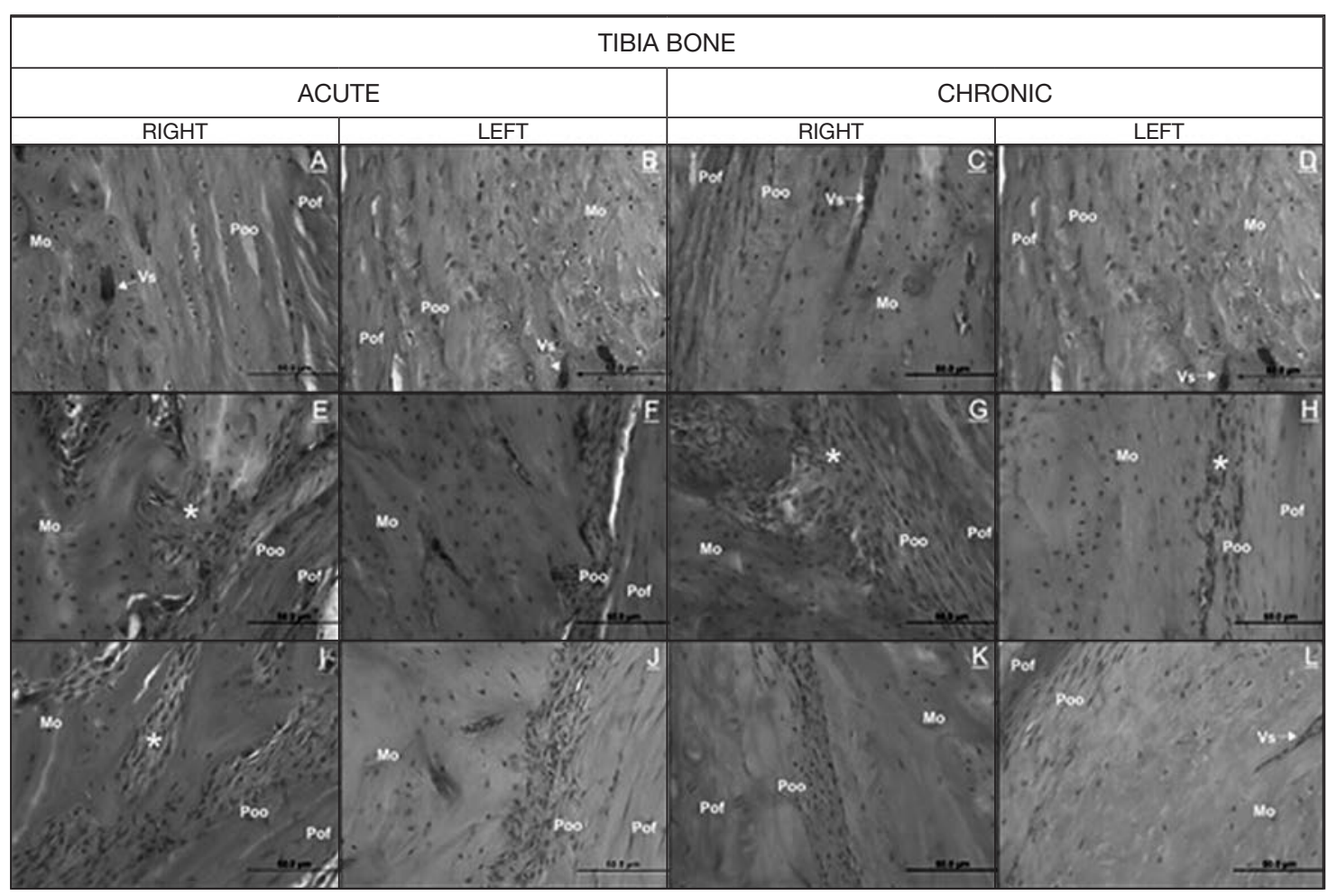

Figure 5. Photomicrographs of the tibia, periarticular peripheral region, acute and chronic inflammatory periods, right and left, respectively. Longitudinal section, hematoxylin, and eosin staining. CG (A, B, C, D) normal aspects of bone tissue, periosteum in its fibrous (Pof) and osteogenic (Poo) layers, bone matrix (Mo) with the presence of blood vessels (Bv). IG (E, F, G, H) tissue denotes the presence of inflammatory cells and modification of the compact bone to spongy bone feature (asterisk). LaIG (I, J), the acute inflammatory period, has morphological aspects similar to IG. LalG in the chronic inflammatory period (K, L), show similarities to the CG with tissue remodeling.

sP and CGRP ${ }^{10}$, which enhance peripheral inflammation. One study has inferred that a sensitive nerve contralateral to arthritis induction, leads to action potentials towards the periphery; also observed that animals induced to an inflammatory process by FCA, presented greater spontaneous antidromic activity when compared to a control group. In their study, they found that the contralateral joints showed plasma leakage due to the presence of sP and CGRP, reaffirming the neuronal action in the formation of the symmetrical lesional pattern of $\mathrm{RA}^{11}$. In this study, it was found that the synovial membrane and bone tissue of the non-sensitized pelvic limb in IG animals showed aspects of cell hyperplasia.

Another study demonstrated that LIL suppresses the signaling of afferent fibers and modulates synaptic transmission to neurons in the dorsal horns, and inhibition of sP, supporting the neural mechanisms of the effectiveness of laser therapy in painful conditions ${ }^{12}$. The synovial membrane is innervated by positive sP fibers, which indicates that it is the inflammatory stimulus that potentiates $\mathrm{RA}^{3}$. The results found in this study corroborate the other findings that demonstrated laser therapy actions in reducing synovial membrane hyperplasia ${ }^{13}$. In the same vein, a systematic review to evaluate the effectiveness of LIL in the treatment of RA concluded that the therapy has a beneficial effect when used for at least four weeks, with effects in reducing pain and morning stiffness, symptoms reported by affected patients ${ }^{14}$. The tissue initially affected by inflammation in RA is the synovial membrane, denoting cellular hyperplasia, and an inflammatory process that characterizes the synovitis process ${ }^{2}$. The animals in the injury groups showed morphological changes with an intense inflammatory process. In cases of disease progression without proper treatment, inflammatory events progress to other tissues, with joint destruction and bone loss.

Periarticular bone changes in RA patients are caused by bone increase and resorption resulting from the accumulation of inflammatory cells, including lymphocytes and macrophages, and pro-inflammatory cytokines that promote osteoclast-mediated bone resorption. Qualitative changes in periarticular bone in RA are poorly studied, but of great interest, as affected patients are prone to fractures due to tissue fragility caused by bone $\operatorname{loss}^{15}$. In this study, the morphology of the bone tissue of the femur and tibia in the periarticular region of rats submitted to experimental RA was evaluated. It was found that IG animals showed bone changes resulting from an intense inflammatory process.

Histopathological analyses have shown a significant reduction in inflammation, bone destruction, cartilage, and pannus formation with other forms of therapy ${ }^{16}$. However, there is no clinical evidence regarding the relationship between LIL and periarticular bone analysis. The decrease in bone strength associated with chronic inflammation, together with significant changes in bone quality and structure, can increase bone susceptibility to failure under low energy load ${ }^{17}$.

The animals that were treated with LIL in the bone morphological aspects in the chronic inflammatory period showed tissue remodeling. It is suggested that the treatment provided an increase in me- 
tabolism, in addition to modulation of the inflammatory process in the experimental period. LIL causes vasodilation, a relevant factor for joint inflammation, as it increases local oxygen support and contributes to the migration of immune cells ${ }^{18}$ helping tissue repair ${ }^{19-23}$. A study that evaluated the effects of LIL on the modulation of the inflammatory process, using an experimental model with animals, concluded that the treatment has better effects when administered in the chronic phases of the disease ${ }^{19}$. They also infer that the $660 \mathrm{~nm}$ wavelength is the most suitable in this phase and that a treatment plan of three sessions, with an interval of 1 day between them, is sufficient to modulate the inflammatory profile of the disease. In this study, it was found that the $660 \mathrm{~nm}$ wavelength stimulated discreet cell organization and reorganization of adipocytes, denoting tissue recovery.

LIL has differentiated actions on tissues, according to the parameters of use, such as dose, wavelength, continuous or pulsed mode, duration and place of treatment, and anti-inflammatory effects when used in disease progression ${ }^{19,20}$. The therapy has biostimulating properties, causing increased cellular metabolism, collagen synthesis, analgesic, and anti-inflammatory effects ${ }^{5,21}$. According to a study, the use of the $670 \mathrm{~nm}$ wavelength showed satisfactory results as an expression of vascular endothelial growth factors ${ }^{22}$. In this study, the wavelength used was $660 \mathrm{~nm}$ and showed tissue morphological improvement when compared to animals in the $\mathrm{IG}^{22}$.

The initial hypothesis of the study was to verify whether the experimental model of disease induction reflected in morphological changes in periarticular tissues and to evaluate whether treatment with LIL would be effective in reducing the harmful effects of the injury. However, the hypothesis can be confirmed due to the changes found in the animals of the injury groups, which denotes an intense periarticular inflammatory process. The LIL has also been shown to be effective in morphologically reducing these effects, even if it does not promote tissue restoration. Also, the study is limited by the protocol with male animals, and the prevalence in humans is in the female gender ${ }^{24-27}$.

It is suggested to conduct studies specifically related to bone tissue morphometry to corroborate the morphological findings of this study. Still, other LIL parameters, such as intensity, dose and wavelength, should be tested, so that the findings can be used in the clinical practice.

\section{CONCLUSION}

The LIL showed beneficial effects on the morphology of the periarticular tissues of rats submitted to experimental rheumatoid arthritis.

\section{REFERENCES}

1. Chen J, Wu W, Zhang M, Chen C. Taraxasterol suppresses inflammation in IL-1 $\beta-$ -induced rheumatoid arthritis fibroblast-like synoviocytes and rheumatoid arthritis progression in mice. Int Immunopharmacol. 2019;70(333):274-83.

2. Macedo RB, Kakehasi AM, Melo de Andrade MV. IL33 in rheumatoid arthritis: potential contribution to pathogenesis. Rev Bras Reumatol. 2016;56(5):451-7. English, Portuguese.
3. Saxler G, Löer F, Skumavc M, Pförtner J, Hanesch U. Localization of SP- and CGRP-immunopositive nerve fibers in the hip joint of patients with painful osteoarthritis and of patients with painless failed total hip arthroplasties. Eur J Pain. 2007;11(1):67-74.

4. Sorkin LS, Eddinger KA, Woller SA, Yaksh TL. Origins of antidromic activity in sensory afferent fibers and neurogenic inflammation. Semin Immunopathol. 2018;40(3):237-47.

5. Smith KC. Molecular targets for low level light therapy. Laser Therapy. 2010;19(3):135-42.

6. White PF, Zafereo J, Elvir-Lazo OL, Hernandez H. Treatment of drug-resistant fibromyalgia symptoms using high-intensity laser therapy: a case-based review. Rheumatol Int. 2018;38(3):517-23.

7. Gomes RP, Bressan E, Silva TM, Gevaerd Mda S, Tonussi CR, Domenech SC. Standardization of an experimental model suitable for studies on the effect of exercise on arthritis. Einstein. 2013;11(1):76-82. English, Portuguese.

8. Reginato A, Neves M, Tavares ALF, Kakihata CMM, Ribeiro LFC, Bertolini GRF. Effects of low-level laser on muscle tissue of wistar rats after. Varia Sci. 2018;4(2):171-5.

9. Stein T, Souza-Silva E, Mascarin L, Eto C, Fin FE, Tonussi CR. Histaminergic pharmacology modulates the analgesic and antiedematogenic effects of spinally injected morphine. Anesth Analg. 2016;123(1):238-43.

10. Groetzner P, Weidner C. The human vasodilator axon reflex - An exclusively peripheral phenomenon? Pain. 2010;149(1):71-5.

11. Sousa-Valente J, Brain SD. A historical perspective on the role of sensory nerves in neurogenic inflammation. Semin Immunopathol. 2018;40(3):229-36.

12. Kelly S, Dunham JP, Donaldson LF. Sensory nerves have altered function contralateral to a monoarthritis and may contribute to the symmetrical spread of inflammation. Eur J Neurosci. 2007;26(4):935-42.

13. Yan W, Chow R, Armati PJ. Inhibitory effects of visible 650-nm and infrared 808nm laser irradiation on somatosensory and compound muscle action potentials in rat sciatic nerve: Implications for laser-induced analgesia. J Peripher Nerv Syst. 2011;16(2):130-5.

14. Carvalho CM, Lacerda JA, Dos Santos Neto FP, De Castro ICV, Ramos TA, De Lima FO, et al. Evaluation of laser phototherapy in the inflammatory process of the rat's TMJ induced by carrageenan. Photomed Laser Surg. 2011;29(4):245-54.

15. Brosseau L, Robinson V, Wells G, Debie R, Gam A, Harman K, et al. Low level laser therapy (Classes I, II and III) for treating rheumatoid arthritis. Cochrane Database Syst Rev. 2005;19(4):CD002039.

16. Shimizu T, Takahata M, Kimura-Suda H, Kameda Y, Endo K, Hamano H, et al Autoimmune arthritis deteriorates bone quantity and quality of periarticular bone in a mouse model of rheumatoid arthritis. Osteoporos Int. 2017;28(2):709-18.

17. Kanbe K, Oh K, Chiba J, Inoue Y, Taguchi M, Yabuki A. Analysis of mitogen-activated protein kinases in bone and cartilage of patients with rheumatoid arthritis treated with abatacept. Clin Med Insights Arthritis Musculoskelet Disord. 2016;9(Il):51-6.

18. Takahata M, Maher JR, Juneja SC, Inzana J, Xing L, Schwarz EM, et al. Mechanisms of bone fragility in a mouse model of glucocorticoid-treated rheumatoid arthritis: Implications for insufficiency fracture risk. Arthritis Rheum. 2012;64(11):3649-59.

19. Issa JPM, Trawitzki BF, Ervolino E, Macedo AP, Lilge L. Low-intensity laser therapy efficacy evaluation in FVB mice subjected to acute and chronic arthritis. Lasers Med Sci. 2017;32(6) 1269-77.

20. das Neves LM, Leite GP, Marcolino AM, Pinfildi CE, Garcia SB, de Araújo JE, et al. Laser photobiomodulation (830 and $660 \mathrm{~nm}$ ) in mast cells, VEGF, FGF, and CD34 of the musculocutaneous flap in rats submitted to nicotine. Lasers Med Sci. 2017;32(2):335-41.

21. Huang Z, Chen J, Ma J, Shen B, Pei F, Kraus VB. Effectiveness of low-level laser therapy in patients with knee osteoarthritis: a systematic review and meta-analysis. Osteoarthritis Cartilage. 2015;23(9):1437-44.

22. Hurkmans EJ, Jones A, Li LC, Vlieland TP. Quality appraisal of clinical practice guidelines on the use of physiotherapy in rheumatoid arthritis: a systematic review. Rheumatology. 2011;50(10):1879-88.

23. da Silva MM, Albertini R, de Tarso Camillo de Carvalho P, Leal-Junior ECP, Bussadori SK, Vieira SS, et al. Randomized, blinded, controlled trial on effectiveness of photobiomodulation therapy and exercise training in the fibromyalgia treatment. Lasers Med Sci. 2018;33(2):343-51.

24. Rueda-Vergara R, Sánchez-Pérez E. Efectividad de la terapia láser de baja intensidad en pacientes con artritis reumatoide: una revisión sistemática de ensayos clínicos. Fisioterapia. 2016;38(3):152-8.

25. Alves AC, de Carvalho PT, Parente M, Xavier M, Frigo L, Aimbire F, et al. Low-level laser therapy in different stages of rheumatoid arthritis: a histological study. Lasers Med Sci. 2013;28(2):529-36.

26. Takhtfooladi MA, Jahanbakhsh F, Takhtfooladi HA, Yousefi K, Allahverdi A. Effect of low-level laser therapy $\left(685 \mathrm{~nm}, 3 \mathrm{~J} / \mathrm{cm}^{2}\right)$ on functional recovery of the sciatic nerve in rats following crushing lesion. Lasers Med Sci. 2015;30(3):1047-52.

27. Lemos GA, Rissi R, de Souza Pires IL, de Oliveira LP, de Aro AA, Pimentel ER, et al. Low-level laser therapy stimulates tissue repair and reduces the extracellular matrix degradation in rats with induced arthritis in the temporomandibular joint. Lasers Med Sci. 2016;31(6):1051-9. 